\title{
The Fourth Industrial Revolution and a New Policy Agenda for Undergraduate Legal Education and Training in England And Wales
}

\author{
Andra le Roux-Kemp*
}

\section{Abstract}

While the full impact of the Fourth Industrial Revolution remains uncertain, it is by now generally accepted that highly intelligent technologies and their applications - such as robotics, artificial intelligence (AI), machine learning, digitisation, and big Data - will continue to fundamentally transform all aspects of our occupational and personal lives. Yet, in the realm of higher education policy and specifically with regard to non-STEM disciplines like law, thorough-going engagement with this most recent wave of technological development remains lacking. It is the aim of this article to set a policy agenda for undergraduate legal education and training that is sensitive to the opportunities and potential negative outfall of the Fourth Industrial Revolution (now exacerbated by COVID-19), while also taking into consideration the distinctive nature of legal education and training in England and Wales. Set against the higher education policy landscape of England and Wales, a number of concrete recommendations are made for bringing undergraduate legal education and training into the age of the Fourth Industrial Revolution. These include, for example, a call for the radical transformation of the traditional, linear, and monodisciplinary LLB degree, addressing current and projected skills gaps and skills shortages by way of, inter alia, curriculum reform, and working towards greater mobility of law graduates between different legal jurisdictions and also within one jurisdiction but amongst different roles. These changes are necessary as legal education and training in England and Wales currently leave law graduates ill-equipped for the future labour market and do not adequately value and build on the job-tasks that legal professionals uniquely supply.

\section{Introduction}

\footnotetext{
* Associate Professor, Lincoln Law School, University of Lincoln (UK); Member of the International Centre for Higher Education Management (ICHEM), University of Bath (United Kingdom).
} 
Modern technology may fundamentally change the way in which law is practised and clients receive legal services. Clerks and assistants working for months and at high hourly rates are no longer required to scrutinise, for example, innumerable documents for the purpose of disclosure/discovery, as computer software can now perform this task at a fraction of the time and with similar - if not better - accuracy. Paralegals and legal secretaries are seemingly also becoming redundant as user-friendly and comprehensive databases, coupled with highly discerning searching software, now allow for easily accessible, thorough-going, and swift legal research solutions. This is the age of the Fourth Industrial Revolution (4IR), in which highly intelligent technologies and their applications - including robotics, artificial intelligence (AI), machine learning, digitalisation, ${ }^{1}$ and big data - transform all aspects of our occupational and personal lives. Indeed, the 4IR may give rise to legal practice being significantly transformed; with fewer people being employed in the legal sector, as human labour is substituted by machines.

For the general workforce, the 4IR elicit angst about the future of manual labour and the sustainability of the existing labour market. ${ }^{2}$ At the one extreme it is suggested that whole occupations will be automated by technology, ${ }^{3}$ while others argue that even those occupations labelled as being at a high-risk for automation will nonetheless retain a substantial share of tasks that are hard - if not impossible - to automate. ${ }^{4}$

\footnotetext{
${ }^{1}$ Digitisation refers to the process or technique for "transforming information stored on physical things (paper documents, photos, microfilms) into series of numbers (bites and bytes)." While digitalisation refers to the "spreading and adoption of digitised technologies in various areas of life or the "[creation of] and environment for digital business'." Tibor Tajti, 'The Impact of Technology on Access to Law and the Concomitant Repercussions: Past, Present, and the Future (from the 1980s to present time)' (2019) 24(2) Uniform Law Review, 400, quoting from Daniel R.A. Schallmo, Digital Transition Now! Guiding the Successful Digitalisation of your Business Model (Springer 2018), para 2.4.

2 Joel Mokyr et al., 'The History of Technology Anxiety and Economic Growth: Is this Time Different?' (2015) 29(3) The Journal of Economic Perspectives, 31-50; David Autor, 'Polanyi's Paradox and the Shape of Employment Growth' (NBER Working Paper Series 20485, 2014)

<https://www.nber.org/papers/w20485.pdf> accessed June 2021.

${ }^{3}$ See generally, Carl B. Frey and Michael Osborne, 'The Future of Employment: How Susceptible are Jobs to Computerisation?' (2013)

<https://www.oxfordmartin.ox.ac.uk/downloads/academic/The_Future_of_Employment.pdf> accessed June 2021, and Mika Pajarinen and Petri Rouvinen, 'Computerisation Threatens One Third of Finnish Employment' (ETLA Muistiot Brief No. 22, 2014) <http://pub.etla.fi/ETLA-Muistio-Brief-22.pdf> accessed June 2021. Also see Melanie Arntz et al., 'The Risk of Automation for Jobs in OECD Countries: A Comparative Analysis' (OECD Social, Employment and Migration Working Papers No. 189, 2016) <https://www.oecd-ilibrary.org/docserver/5jlz9h56dvq7en. pdf?expires $=1578172632 \& \mathrm{id}=\mathrm{id} \&$ accname $=$ guest $\&$ checksum=A098B5E211CAC63D4D88A0DB93 857F8F> accessed June 2021.

${ }^{4}$ David Autor et al., 'The Skill Content of Recent Technological Change: An Empirical Exploration' (2003) 118(4), The Quarterly Journal of Economics, 1279-1333; Melanie Arntz et al., 'The Risk of
} 
Business leaders do not display a similar concern for the future of human labour, but are rather concerned about staying abreast (and ahead) of these technologies; fearing being caught out by market disruption or being left behind. ${ }^{5}$ As world economies continue to adapt to the new possibilities of automation and technology-driven markets, the actual impact and consequences of 4IR remain uncertain. ${ }^{6}$

This, however, does not mean that the various market sectors can stand idly by, waiting for the revolution wrought by digital technologies to be realised. ${ }^{7}$ It is imperative for policies, plans, and strategies to be put in place to not only guide individuals, businesses, and governments to take maximum advantage of the opportunities that the 4IR has to offer, but also to mitigate possible negative impacts resulting from, for example, the displacement of human labour. ${ }^{8}$ Yet, according to a 2018 report by The Economist Intelligence Unit Ltd, "very few countries have begun to address the impact and challenges of artificial intelligence and robotics-based automation in the areas of innovation, education, and the labour market". ${ }^{9}$ In terms of education policy specifically, "[i]ntelligent automation is expected to boost the importance of both education related to STEM (science, technology, engineering and mathematics) and of so-called soft skills, which allow workers to trade on their uniquely human capabilities". 10 Evidence of "initiatives in areas such as curriculum reform, lifelong learning, occupational training and workplace flexibility", nevertheless remain sparse, both in terms of its quantity and quality. ${ }^{11}$ For example, at the level of higher education, education policies aimed specifically at the reform of higher education for the new automated and technology-driven labour market, largely remain limited to the

Automation' supra n 3, 4; Terry Gregory et al., 'Racing With or Against the Machine? Evidence from Europe' (Discussion Paper No. 16-053 Zentrum für Europäische Wirtschaftsforschung GmbH (Centre for European Economic Research) July 2016), <http://ftp.zew.de/pub/zew-docs/dp/dp16053.pdf> accessed June 2021.

5 The Economist Intelligence Unit Ltd., The Automation Readiness Index: Who is ready for the coming wave of automation? (2018), 5 <http://www.automationreadiness.eiu.com/static/download/PDF.pdf> accessed June 2021.

6 lbid, 5,7 and 21.

7 Ibid, 21; Lutfey Siddiqi, 'Confronting the Macroeconomic Challenges of the Fourth Industrial Revolution' (LSE Business Review, 2019)

$<$ https://blogs.Ise.ac.uk/businessreview/2018/01/17/confronting-the-macroeconomic-challenges-ofthe-fourth-industrial-revolution/> accessed June 2021.

8 The Economist Intelligence Unit Ltd., The Automation Readiness Index, supra n 5, 5; Arntz et al., 'The Risk of Automation' supra n 3, 7; Frey and Osborne, 'The Future of Employment' supra n 3, 13.

9 The Economist Intelligence Unit Ltd., The Automation Readiness Index, supra n 5, 5.

10 lbid, 6.

$11 \mathrm{lbid}, 5$, and 15-17. 
promotion of STEM programmes and in ensuring more equitable and representative enrolment of students. ${ }^{12}$ And while emphasis is also placed on the importance of collaboration with industry in ensuring work-ready graduates, and the new and exciting possibilities technology has to offer for learning environments, non-STEM disciplines continue to remain at the periphery of these developments.

The focus of this article is on the Fourth Industrial Revolution and undergraduate legal education and training in England and Wales, and specifically on policy considerations that can inform meaningful change in how we train the legal professionals ${ }^{13}$ of the future. It will be shown that policy and guidance are necessary and warranted in steering the legal profession, and the education and training of its members, through the current technological wave and in preparation for the new challenges the legal sector and market will face. The goal of this article is therefore to serve policy development in how the undergraduate education and training of legal professionals can be transformed to better equip graduates for an automated and technology-driven labour market of the future.

First, a general overview is provided of what is commonly referred to as the Fourth Industrial Revolution. The 4IR is not a specific time period or epoch in the history of mankind, but rather refers to a wave of technological development over a period of time that has (had) a significant and widespread impact on all aspects of people's lives. A general overview of existing education policies that have developed as a consequence as well as in anticipation of the effects and impact of the 4IR, will also be considered. The focus is decidedly on the United Kingdom Department for Education and specifically on the undergraduate legal education and training in England and Wales. Instead of focussing on LawTech (Legal Technology) ${ }^{14}-$ the application of advanced technologies in the legal services sector - in setting a policy agenda for undergraduate legal education and training in England and Wales, this

\footnotetext{
12 Ibid.

${ }^{13}$ All references to the legal profession or legal professionals in this article refer to the English legal profession which has two distinct branches; solicitors and barristers, respectively regulated and represented by their professional bodies the Law Society and the Bar Council.

14 The term LawTech was inspired by the related term FinTech and essentially refers to disruptive technologies which impact significantly on the named market sector in all respects, from the daily routines of their workers and the job-tasks they perform, to the manner by which, and the type of services provided. Tajti, ‘The Impact of Technology' supra n 1, 397.
} 
article will rather consider more fundamentally the tenets upon which legal education and training in England and Wales are currently based. Are these still appropriate in the wake of the Fourth Industrial Revolution? Or is it maybe time for sacred-cows to be reconsidered?

\section{The Fourth Industrial Revolution: What, If Anything, Is Different This Time?}

The substitution of low-skill, routine, and repetitive human labour with industrial processes and machinery, is an age-old phenomenon. ${ }^{15}$ For example, in the eighteenth century, water and steam were used to mechanise production and in the late nineteenth century, new forms of power generation, specifically electricity, were used to drive mass production. With each new stage of technological innovation and development came about "enormous wealth, but also undesired disruptions." 16 Yet, it was only with the advent of computerisation in the twentieth century, that human (manual) labour was significantly displaced by machines. This was largely due to the use of electronics and information technology (including the Internet of Things), in equipping machines - specifically computers - to perform symbolic processing tasks like storing, retrieving, and acting upon information. ${ }^{17}$ What later became known as the Third Industrial Revolution of the twentieth century, therefore marked a qualitative enlargement in the set of tasks that machines could perform. ${ }^{18}$ During this time, for example, computers substituted, to a large extent, "for the calculating, coordinating and communicating functions of bookkeepers, cashiers, telephone operators, and other handlers of repetitive information-processing tasks." 19

Routine tasks, in this context, should not be understood as referring to "mundane" jobtasks, but rather refer to "codifiable" tasks; in other words, those tasks that can be fully specified in a series of instructions to be executed by a machine. ${ }^{20}$ To date, the capability of computers to substitute for human labour in carrying out non-routine tasks or cognitive tasks remain limited, as these tasks do not (easily) lend themselves to

\footnotetext{
15 Autor et al., 'The Skill Content' supra n 4, 1284.

16 Frey and Osborne, 'The Future of Employment' supra n 3, 5.

17 Autor et al., 'The Skill Content' supra n 4, 1284.

18 Ibid.

$19 \mathrm{lbid}$

20 Daron Acemoglu and David Autor, 'Chapter Twelve: Skills, Tasks and Technologies: Implications for Employment and Earnings' in David Card and Orley Ashenfelder (eds.) Handbook of Labour Economics (Elsevier, 2011), 1076.
} 
computerisation. ${ }^{21}$ This is because non-routine or cognitive tasks generally demand "flexibility, creativity, generalised problem-solving, and complex communications", 22 and these complex capabilities are difficult - and once thought near impossible - to translate into explicit programmed instructions. Yet, the more recent production of increasingly large and complex datasets, known as Big Data, are now making the computerisation of non-routine tasks a real possibility; as the combination of such datasets together with advanced technologies, increasingly allow for machines to "probabilistically emulate [human] behaviour under analogous conditions". ${ }^{23}$ This new digital transformation "is powered by the cloud, social media, mobile computing, the internet of things (IoT) and artificial intelligence ( $\mathrm{Al}$ ), along with increased power and data", and is generally referred to as the Fourth Industrial Revolution. ${ }^{24}$ In this sense, the Fourth Industrial Revolution can be regarded as a continuation of the Third Industrial Revolution but with the impact of computerisation no longer confined to routine tasks that can be written as rule-based software queries. ${ }^{25}$ Increasingly, therefore, computerisation - and specifically automation - is displacing human labour.

The impact of computerisation or automation on human labour has been considered in terms of two approaches: An occupation-based approach to the estimation of jobsecurity in light of the $4 \mathrm{IR}$, paints a rather dark picture for the future, as it postulates the displacement of whole occupations from the current labour market. ${ }^{26}$ For example, in 2013 , Frey and Osborne submitted that $47 \%$ of the workforce in the United States of America are at risk of being automated. ${ }^{27}$ Of this, persons working in bookkeeping, accounting, and auditing are said to face an automation potential of $98 \%$, while those working in retail sales face an automation potential of $92 \% .{ }^{28}$ Such automation scenarios based on an occupation-based approach have been criticised, however, for

\footnotetext{
21 Autor et al., 'The Skill Content' supra n 4, 1284.

22 Ibid.

23 Daniel M. Katz, 'Quantitative Legal Prediction - or - how I Learned to Stop Worrying and Start Preparing for the Data-driven Future of the Legal Services Industry' (2013) 62 Emory Law Journal, 909-966.

24 Frey and Osborne, 'The Future of Employment' supra n 3, 15-16.

25 Ibid.

26 See, for example, Mika Pajarinen and Petri Rouvinen, 'Computerisation Threatens One Third of Finnish Employment' (ETLA Muistiot Brief No. 22, 2014) <http://pub.etla.fi/ETLA-Muistio-Brief-22.pdf> accessed June 2021 and Frey and Osborne, 'The Future of Employment' supra $\mathrm{n} 3$.

${ }^{27}$ Frey and Osborne, 'The Future of Employment' supra n 3; Arntz et al., 'The Risk of Automation' supra n 3, 14.

${ }^{28}$ Frey and Osborne, 'The Future of Employment' supra n 3, 60 and 71; Arntz et al., 'The Risk of Automation' supra n 3, 14.
} 
having a rather narrow and simplified view of the myriad of diverse job-tasks any particular occupation may involve in practice. ${ }^{29}$ Conversely, a task-based approach to the estimation of job-security presents a less dire foretelling, and emphasises that "jobs at risk" should not be equated with actual or expected employment losses due to technological advances and automation. ${ }^{30}$ In other words, it is not occupations that are displaced by technological advances, but rather certain tasks that are at risk of being automated. ${ }^{31}$ Applying a task-based approach to automation scenarios therefore suggest that the 4IR will not be as disruptive as once feared, as the uptake of new technologies is a relatively slow process and even where new technologies are introduced workers can adjust to changing technological endowments by, for example, switching tasks or acquiring new skills to fill new positions, etc. ${ }^{32}$ This is consonant with experiences of past technological advances in the nineteenth and twentieth century, when the creation of new jobs and different job-tasks within existing occupations tended to outpace the labour-saving impact of the adoption of new technologies. ${ }^{33}$

Yet, many believe that the 4IR will indeed be different, particularly as "automation and digitalisation are increasingly penetrating the domain of tasks that until recently used to be genuinely human, such as reasoning, sensing, and deciding". ${ }^{34}$ Examples of machines capable of performing non-routine cognitive tasks include driverless cars, largely autonomous smart factories, service robots, and 3D printing. ${ }^{35}$ In addition to

\footnotetext{
${ }^{29}$ Arntz et al., 'The Risk of Automation' supra n 3, 12.

${ }^{30}$ See, for example, David Autor et al., 'Computer-based Technological Change and Skill' in Eileen Appelbaum et al. (eds.) Low-Wage America - How Employers are Reshaping Opportunity in the Workplace (Russell Sage Foundation, 2006), 121-154; David Autor, 'The "Task Approach" to Labour Markets: An Overview' (2013) 46(3) Journal for Labour Market Research, 185-199; Arntz et al., 'The Risk of Automation' supra n 3, 4.

${ }^{31}$ Arntz et al., 'The Risk of Automation' supra n 3, 8.

$32 \mathrm{lbid}$, 4. Also see Daron Acemoglu and David Autor, 'Chapter Twelve: Skills, Tasks and Technologies: Implications for Employment and Earnings' in David Card and Orley Ashenfelder (eds.) Handbook of Labour Economics (Elsevier, 2011), 1055-1089 and Francis Green, 'Employee Involvement, Technology and Evolution in Job Skills: A Task-Based Analysis' (2012) 65(1) Industrial and Labour Relations Review, 64.

${ }^{33}$ In 1931, John Maynard Keynes predicted widespread technological unemployment "due to our discovery of means of economising the use of labour outrunning the pace at which we can find new uses for labour.” John M. Keynes, 'Economic Possibilities for our Grandchildren' in John M. Keynes Essays in Persuasion (Harcourt Brace, 1931), 400. Arntz et al., 'The Risk of Automation' supra n 3, 78; Mokyr et al., 'The History of Technology Anxiety' supra n 2, 31-50.

${ }^{34}$ Arntz et al., 'The Risk of Automation' supra n 3, 7; The Economist Intelligence Unit Ltd., The Automation Readiness Index, supra n 5, 7.

$35 \mathrm{lbid}, 7$.
} 
the technological advances of the 4IR redefining what type of human capabilities machines are able to perform, ${ }^{36}$ the accelerated pace of technological advancement and change also make the 4IR distinct from previous industrial revolutions: ${ }^{37}$

The possibilities of billions of people connected by mobile devices, with unprecedented processing power, storage capacity, and access to knowledge, are unlimited. And these possibilities will be multiplied by emerging technology breakthroughs in fields such as artificial intelligence, robotics, the Internet of Things, autonomous vehicles, 3-D printing, nanotechnology, biotechnology, materials science, energy storage, and quantum computing. ${ }^{38}$

This fast pace of technological advancement and change may also account for the apparent slow uptake in policies, plans, and strategies dealing with both the positive opportunities, as well as the potential negative outfall of the 4IR. It seems that the lack of depth in our understanding of the 4IR and where it may lead (us), as well as the possible futility of putting policies and strategies in place that are likely to be irrelevant or ineffective by the time that they come to fruition or must be implemented, ${ }^{39}$ are inhibiting any and all policy action in this regard. 40

Despite the uncertainty surrounding the potential impact and consequences of the 4IR, two areas of broad consensus can be discerned: It is firstly accepted that automation technologies will replace certain tasks performed by workers as much, or more, than they replace entire jobs. And it is further accepted that co-ordinated efforts by multiple stakeholders - including governments, businesses, educators, labour unions and civil society organisations - are required to seize the opportunities and alleviate the strains that intelligent automation will pose to economies worldwide. ${ }^{41}$ However, with regard to higher education specifically, relatively little has been done, and the focus in the

\footnotetext{
${ }^{36}$ Frey and Osborne, 'The Future of Employment' supra n 3, 15; Arntz et al., 'The Risk of Automation' supra $\mathrm{n} 3,7$.

37 See William Nordhaus, 'Are We Approaching an Economic Singularity? Information Technology and the Future of Economic Growth' (NBER Working Paper Series Nr. 21547, 2015) $<$ https://www.nber.org/papers/w21547.pdf> accessed June 2021; Mokyr et al., 'The History of Technology' supra n 2, 47; The Economist Intelligence Unit Ltd., The Automation Readiness Index, supra $\mathrm{n} 5,7$.

${ }^{38}$ Klaus Schwab, The Fourth Industrial Revolution (World Economic Forum, 2016), 7.

39 The Economist Intelligence Unit Ltd., The Automation Readiness Index, supra n 5, 7.

40 lbid, 21.

41 lbid, 7.
} 
United Kingdom, as in many other countries the world over, has rather been on the "employability" of graduates and graduates' individual responsibility to be ready and remain competitive in a fast-changing job market. ${ }^{42}$ It is submitted in this article that despite the imagined future of the 4IR remaining uncertain, we already know enough for concerted action, also in the realm of higher education and training:

Technology is not an exogenous force over which we have no control. We are not constrained by a binary choice between 'accept and live with it' and 'reject and live without it'. Instead, take dramatic technological change as an invitation to reflect about who we are and how we see the world. ${ }^{43}$

\section{Education Policies In The Age Of The Fourth Industrial Revolution: Charting The Landscape}

According to the 2018 report by The Economist Intelligence Unit Ltd, there is at present "plenty of thinking but very little planning or action" as to what a long-term strategy for education and training in an automated economy should entail. ${ }^{44}$ This dearth of direction and planning on the education and training needed for an automated economy appears to be a global spectacle, ${ }^{45}$ but not necessarily due to laziness or inattention of governments and education departments, but is rather due to "the enormous number of unknowns about precisely how automation technologies will affect the workforce and what types of responses will be effective." 46

The focus and scope of existing education policies for the 4IR can be summarised as follows: 47

\footnotetext{
42 Jamie Morgan, 'The Fourth Industrial Revolution could lead to a Dark Future' (The Conversation, 9 January 2020), <https://theconversation.com/the-fourth-industrial-revolution-could-lead-to-a-darkfuture125897?utm_medium=email\&utm_campaign=Latest $\% 20$ from $\% 20$ The $\% 20$ Conversation $\% 20$ for\%20Ja nuary $\% 2010 \% 202020 \% 20-$

\%201505114325\&utm_content=Latest $\% 20$ from \%20The\%20Conversation\%20for\%20January $\% 2010$ $\% 202020 \% 20-$

$\% 201505114325+$ CID 7822f43ad4eb934b8b340f04ef884093\&utm source=campaign monitor uk\&u tm_term $=$ The $\% 20$ fourth\%20industrial\%20revolution\%20could\%20lead\%20to\%20a\%20dark\%20future $>$ accessed June 2021.

${ }^{43}$ Schwab, The Fourth Industrial Revolution supra n 38, 9.

44 The Economist Intelligence Unit Ltd., The Automation Readiness Index, supra n 5, 15.

45 lbid.

46 lbid, 21.

$47 \mathrm{lbid}, 9$, and 27-28.
} 


\begin{tabular}{|c|c|}
\hline \multicolumn{2}{|c|}{ Education Policies } \\
\hline Sub-Category & Focus-area \\
\hline \multirow[t]{3}{*}{ Basic (Compulsory) Education } & $\begin{array}{l}\text { Early childhood education and } \\
\text { development programmes } \\
\text { Cultivating and integrating } 21^{\text {st }} \text { century } \\
\text { skills and knowledge (e.g. soft skills such } \\
\text { as critical thinking, communication, } \\
\text { collaboration, creativity, and problem- } \\
\text { solving skills) in relevant curricula }\end{array}$ \\
\hline & $\begin{array}{l}\text { Cultivating and integrating technical } \\
\text { skills and knowledge (e.g. technology } \\
\text { education programmes (STEM) and data } \\
\text { literacy) in relevant curricula }\end{array}$ \\
\hline & Career guidance programmes \\
\hline & $\begin{array}{l}\text { Promoting technology } \\
\text { programmes (STEM) }\end{array}$ \\
\hline Higher Education & $\begin{array}{l}\text { Education policies promoting access to } \\
\text { higher education, specifically STEM } \\
\text { programmes and targeting under- } \\
\text { represented groups }\end{array}$ \\
\hline & $\begin{array}{l}\text { Existence and financial support for } \\
\text { lifelong learning programmes }\end{array}$ \\
\hline Contınuous Education & $\begin{array}{l}\text { Training and skills development in (or as } \\
\text { part of) employment }\end{array}$ \\
\hline & $\begin{array}{l}\text { Assessment reform, focussing on } 21^{\text {st }} \\
\text { century skills, as well as technical skills } \\
\text { and knowledge } \\
\text { Educator training reform, to ensure that } \\
\text { teachers are able to deliver education for } \\
\text { skills of the future }\end{array}$ \\
\hline Learning Environments & $\begin{array}{l}\text { Use of technology (including Al, data and } \\
\text { analytics) in the classroom to improve } \\
\text { education outcomes, increase student } \\
\text { interaction with technology, and drive } \\
\text { innovative learning and assessment } \\
\text { processes }\end{array}$ \\
\hline & $\begin{array}{l}\text { Innovation of school models (including } \\
\text { institutional autonomy and curriculum } \\
\text { deregulation) }\end{array}$ \\
\hline & $\begin{array}{l}\text { Promote dialogue between different } \\
\text { stakeholders (including the education } \\
\text { sector, industry, public and private } \\
\text { sectors etc.) to shape and reform } \\
\text { education and training }\end{array}$ \\
\hline
\end{tabular}

A closer evaluation of the application of these education policies for the 4IR generally, and specifically with reference to the policy papers and consultations of the United 
Kingdom Department for Education, reveal the following: ${ }^{48}$ most education policy activities are aimed at basic or compulsory education, as well as continuous education. ${ }^{49}$ First, with regard to basic (compulsory or school-level) education, it is by now generally accepted that a proper grounding in technical skills which are likely to be required in most future roles - such as computational thinking - is paramount for learners' further education and entry to the future labour market. A 2017 Employer Skills Survey found the most persistent skills shortages were in skilled trades (such as technicians), and that this demand for skilled technicians - also for technicians with STEM-skills - will continue to grow in future. ${ }^{50}$ For basic education therefore, the UK Department for Education has developed a policy and roll-out plan for the improvement and expansion of technical education and training at the school level. ${ }^{51}$ Technical education, broadly speaking, "encompasses any training, such as qualifications and apprenticeships, that focuses on progression into skilled employment and requires the acquisition of both a substantial body of technical knowledge and a set of practical skills valued by industry." 52 To this end, a new schoolleaving (exit-level) qualification has been developed and was introduced in phases from September 2020. ${ }^{53}$ The new T-level qualification (Technical Levels) is available to secondary school students alongside the existing GCSEs and A-levels and is described as follows:

A T-level is a rigorous, stretching programme of study at level 3 based on recognised, employer-led standards. T-levels will offer a high quality, prestigious technical alternative to A-levels and be aligned with work-based technical education also delivered at level 3 through apprenticeships. ${ }^{54}$

\footnotetext{
48 Department for Education (UK), 'Policy Papers and Consultations' $<$ https://www.gov.uk/search/policy-papers-and-consultations?organisations $\% 5 \mathrm{~B} \% 5 \mathrm{D}=$ department-foreducation\&parent=department-for-education> accessed June 2021.

49 The Economist Intelligence Unit Ltd., The Automation Readiness Index, supra n 5, 5 and 15-17.

${ }^{50}$ Department for Education (UK), 'Policy Paper Review of Higher Technical Education: Glossary of Terms' (Department for Education (UK) 8 July 2019), 9 $<$ https://assets.publishing.service.gov.uk/government/uploads/system/uploads/attachment data/file/9 07145/Review_of higher_technical_education_-glossary_of_terms.pdf > accessed June 2021.

$51 \mathrm{lbid}$.

52 lbid, 8.

$53 \mathrm{lbid}$.

$54 \mathrm{lbid}$. The general educational framework (or qualifications framework) in England and Wales can be explained as follows: Higher education institutions offer bachelor, master and PhD degree programmes at educational level 6,7 and 8 , while school-leaving certificates can be obtained at educational level 2 or 3 in the form of GCSEs and A-levels (now also T-levels). Educational levels 4 and 5 include a multitude of post-school but sub-bachelor qualifications including apprenticeships,
} 
For post-secondary education - i.e. higher education (HE) - the initiatives and strategies for higher education reform in an automated and technology-driven labour market have almost exclusively focussed on promoting STEM (Science, Technology, Engineering and Mathematics) education programmes and on ensuring access to higher education, specifically a more equitable and representative enrolment of underrepresented groups in STEM programmes. ${ }^{55}$ While these objectives are certainly important, having more people and a more diverse representation of society trained in STEM disciplines cannot be the only strategy for the future digital economy. Indeed, in a 2018 report by UK Comptroller and Auditor General, it was found that there were particular shortages of STEM skills at technician level but that there was an oversupply of STEM graduates in the biological sciences. ${ }^{56}$ This situation was ascribed to, inter alia, the uncertainty in the modelling of future STEM skill needs "due to the difficulty of predicting the effects of technological changes and future events". ${ }^{57}$ It was also noted that "at graduate level and above, the problem is sometimes one of quality rather than quantity, with people not having all of the employability or practical skills they need to enter the workforce". ${ }^{58}$ Evidence of this can arguably be found in the employability rates of STEM graduates, as the data collected for the purpose of this 2018 audit report revealed that of the 75,000 learners who had graduated with a STEM degree in 2016 , only $24 \%$ were known to be working in a STEM occupation within six months. ${ }^{59}$

Technical education and training therefore remain important even at the postsecondary (or post-school) level. Higher Technical Education (HTE) refers to

\footnotetext{
and vocational training offered by further education colleges in the form of BTECs and NVQS. See National Audit Office (UK), 'Delivering STEM (Science, Technology, Engineering and Mathematics) Skills for the Economy' (HC 716 Session 2017-2019, 17 January 2018), 12 <https://www.nao.org.uk/wp-content/uploads/2018/01/Delivering-STEM-Science-technologyengineering-and-mathematics-skills-for-the-economy.pdf> accessed June 2021 and Simon Field, The Missing Middle: Higher Technical Education in England (The Gatsby Charitable Foundation, 2018), 16.

55 The Economist Intelligence Unit Ltd., The Automation Readiness Index, supra n 5, 5, 15-17; National Audit Office (UK), 'Delivering STEM' supra n 54, 5-6; Department for Business, Energy and Industrial Strategy (UK), 'Industrial Strategy: Building a Britain Fit for the Future' (Department for Business, Energy and Industrial Strategy (UK) 27 November 2017), <https://assets.publishing.service.gov.uk/government/uploads/system/uploads/attachment_data/file/6 64563/industrial-strategy-white-paper-web-ready-version.pdf> accessed June 2021.

${ }^{56}$ National Audit Office (UK), 'Delivering STEM' supra n 54, 7.

$57 \mathrm{lbid}$

$58 \mathrm{lbid}$.

$59 \mathrm{lbid}, 9$.
} 
education and training programmes aimed at preparing learners for higher technical occupations. Such occupations vary widely but include nuclear technicians, cybersecurity analysts, and nursing associates. ${ }^{60}$ In the United Kingdom, higher technical education programmes include vocational training, internships, and other shorter (usually part-time) programmes leading to foundation degrees, Higher National Certificates (HNCs), Higher National Diplomas (HNDs), and diplomas and certificates at the post-secondary school; all at sub-bachelor degree (higher education institution) level. ${ }^{61} \mathrm{HTE}$ is valuable as it can serve both as a direct route to employment or as a further qualification for those already in work. ${ }^{62}$ Compared to countries like Germany and France, England (and Wales) is lagging far behind in all respects of HTE. ${ }^{63}$ There are not only fewer higher technical education programmes and service providers available in England and Wales, but learner enrolment in such existing (HTE) programmes remain proportionally low, resulting in mid-level occupationally-relevant skills being in high demand. ${ }^{64}$ Simon Field described this phenomenon in the English education and training setting as the "missing middle":

[T] he missing middle does matter [...] Full-time bachelor's degrees will be largely irrelevant to the changing requirements of an adult workforce facing the need to upskill and reskill in response to the one clear certainty about the future - fastchanging labour market requirements. ${ }^{65}$

A pronounced and robust commitment to lifelong learning and further training and skills development are therefore imperative. It is envisaged that the labour market of the future will not only require of all job-seekers an appropriate level of proficiency in technical skills and twenty-first century competencies, but will also require of workers to showcase a high degree of adaptability and to embrace lifelong learning and skills

\footnotetext{
60 Department for Education (UK), 'Policy Paper Review of Higher Technical Education; supra n 50, 8; Department for Education (UK), 'Policy Paper Higher Technical Education: Current System and Case for Change' (Department for Education (UK) 8 July 2019), <https://assets.publishing.service.gov.uk/government/uploads/system/uploads/attachment_data/file/8 14938/Higher_technical_education_case_for_change.pdf> accessed June 2021.

${ }^{61}$ See generally, Richard Boniface et al., 'Mapping the Higher Technical Education Landscape' (2018) $<$ http://www.gatsby.org.uk/uploads/education/reports/pdf/mapping-the-higher-technical-landscapefinal-version.pdf>; Department for Education (UK), 'Policy Paper Higher Technical Education' supra n 60; Field, The Missing Middle: Higher Technical Education in England, supra n 54, 15.

62 Field, The Missing Middle: Higher Technical Education in England, supra n 54, 5.

63 Ibid, 51-54.

64 Ibid, 12.

65 Ibid, 12.
} 
development throughout their working lives in order to stay abreast the fast-paced development and roll-out of new technologies. ${ }^{66}$ For continuous education and training for the Fourth Industrial Revolution, the UK Department for Education has initiated a National Retraining Scheme to assist adult learners in retraining into better jobs, and also to "be ready for future changes to the economy, including those brought about by automation". ${ }^{67}$ The National Retraining Scheme has been rolled out across England and Wales from 2020, and will initially support adults who are already in work, are aged twenty-four and above, who have a qualification at degree level, and are paid below a certain wage threshold. ${ }^{68}$ The focus of the retraining will be on functional skills training, specifically English, mathematics and digital skills, as well as in-work vocational training. ${ }^{69}$ The aim and purpose for this National Retraining Scheme are directly linked to the new opportunities as well as the potential negative outfall of the $4 \mathrm{IR}$, and has at aim, inter alia, to respond to new opportunities that the future economy will bring, as well as the changing nature of jobs and the types of tasks people generally perform at work. ${ }^{70}$

More generally, the transformation of learning environments to incorporate new technologies in terms of both the learning process and modes of assessment as well as academic administration, have seemingly gained traction at all levels of the

\footnotetext{
66 The Economist Intelligence Unit Ltd., The Automation Readiness Index, supra n 5, 15.

67 Department for Education (UK), 'Policy Paper National Retraining Scheme' (Department for Education (UK), 19 July 2019, updated 16 October 2019)

<https://www.gov.uk/government/publications/national-retraining-scheme/national-retraining-scheme> accessed June 2021. Also see Department for Education (UK), 'Policy Paper National Retraining Scheme: Associated Projects' (Department for Education (UK), 19 July 2019, updated 16 October 2019) <https://www.gov.uk/government/publications/national-retraining-scheme/national-retrainingscheme-associated-projects> accessed June 2021, and Department for Education (UK), 'Policy Paper Improving Adult Basic Skills: Equality Impact Assessment' (Department for Education (UK), April 2019)

<https://assets.publishing.service.gov.uk/government/uploads/system/uploads/attachment_data/file/7 96393/Improving_adult_basic_skills_-_equality_impact_assessment.pdf> accessed June $\overline{2021}$ and Department for Education (UK), 'Unlocking Talent, Fulfilling Potential - A Plan for Improving Social Mobility through Education' (Department for Education (UK) December 2017) <https://assets.publishing.service.gov.uk/government/uploads/system/uploads/attachment_data/file/6 67690/Social_Mobility_Action_Plan_-_for_printing.pdf> accessed June 2021. 68 Department for Education (UK), 'Policy Paper National Retraining Scheme' supra $\mathrm{n} 67$. 69 Ibid; Department for Education (UK), 'Policy Paper Improving Adult Basic Skills' supra n 67; Department for Education (UK), 'Policy Paper Functional Skills English and Mathematics Subject Content: Equality Impact Assessment' (Department for Education (UK), April 2019) $<$ https://assets.publishing.service.gov.uk/government/uploads/system/uploads/attachment_data/file/7 96393/Improving_adult_basic_skills___equality_impact_assessment.pdf $>$ accessed June 2021. ${ }^{70}$ Department for Education (UK), 'Policy Paper National Retraining Scheme' supra n 67.
} 
education sector. ${ }^{71}$ New initiatives and examples of good practices in EdTech include, amongst others, online learning platforms, the use of digital material and sources, big data analysis for more accurate predictions of student performance, and intelligent administrative services. ${ }^{72}$ Liaison with industry and other stakeholders to promote innovation and collaboration in the education sector have largely also been successful, particularly (and arguably most appropriately) in the context of higher education. ${ }^{73}$

Yet, what remains missing from the existing complement of education policies and strategies aimed at transforming education and training for the Fourth Industrial Revolution, is an engagement with non-STEM disciplines, including that of undergraduate legal education and training. The subsequent parts of this article aim to set an agenda for undergraduate legal higher education policy in England and Wales. The recommendations made here are sensitive to the fact that while "big picture thinking" may very well be called for in the age of the $4 \mathrm{IR}$, it must also be recognised that the wheels of education policy and reform turn slowly, and are encumbered with the interests and demands of multiple stakeholders. ${ }^{74}$ Nonetheless, it is submitted that the $4 \mathrm{IR}$ is an opportunity to debate and radically redesign sacred cows like that of undergraduate legal education and training in England and Wales.

\section{Undergraduate Legal Education And Training In England And Wales: Prepared For An Automated World Economy And Labour Market?}

English legal education and training "emerged largely as a creature of the legal profession", and remains so to this day. ${ }^{75}$ Academic legal education in England and Wales dates back to 1758 when the first English (Common) Law Vinerian Professorial

\footnotetext{
${ }^{71}$ See, generally, Department for Education (UK), 'Policy Paper Realising the Potential of Technology in Education: A Strategy for Education Providers and the Technology Industry' (Department for Education (UK) April 2019)

<https://assets.publishing.service.gov.uk/government/uploads/system/uploads/attachment_data/file/7 91931/DfE-Education_Technology_Strategy.pdf> accessed June 2021.

72 Frey and Osborne, 'The Future of Employment' supra n 3, 18; Department for Education (UK),

'Policy Paper Realising the Potential of Technology in Education' supra n 71; Pritchard Breslow et al., 'Studying Learning in the Worldwide Classroom: Research into EdX's First MOOC' (2013) 8 Research \& Practice in Assessment, 13-15; Beverly Woolf, Building Intelligent Interactive Tutors: Studentcentered Strategies for Revolutionising e-learning (Morgan Kaufmann Publishers, 2009).

${ }^{73}$ National Audit Office (UK), 'Delivering STEM' supra n 54, 39.

${ }^{74}$ Werner Jann and Wegrich Kai, 'Theories of the Policy Cycle' in Frank Fischer et al. (eds.) Handbook of Public Policy analysis - Theory, Politics and Methods (CRC Press, 2007), 44-45.

${ }^{75}$ Andrew Boon and Julian Webb, 'Legal Education and Training in England and Wales: Back to the Future?' (2008) 58(1) Journal of Legal Education, 82.
} 
Chair was established at the University of Oxford. ${ }^{76}$ But it was only in 1855 that the first LLB degree was established by the University of Cambridge, and more than two decades thereafter (1921) that the Law Society (the professional regulatory body for solicitors) handed over much of its legal training to the universities of that time. ${ }^{77}$ Whether English law can (or should be) an endeavour for higher education remained the topic of many inaugural lectures and presidential addresses up to the 1950s, and even today, a distinct divide between academic law and the legal profession can often be observed. ${ }^{78} \mathrm{~A}$ comprehensive historical overview of the entangled, and often vexed relationship that exists between the legal professional bodies and law schools and faculties with regard to the education and training of its (the legal professional bodies') members, falls beyond the scope of this article. However, in setting a policy agenda for the reform of undergraduate legal education and training in England and Wales to better equip prospective legal professionals for an automated and technology-driven labour market, the role of the legal professional bodies as the gatekeepers to the profession and currently responsible for the vocational and practical training of its (prospective) members cannot be ignored, and the recommendations below will for this reason also account for the synergism of the LLB degree programme with the vocational and practical training components for admission to the legal profession.

With regard to the undergraduate legal education and training specifically, it can be noted that conventionally, prospective legal professionals in England and Wales will commence their legal education and training - upon completion of their secondary school education - with a three-year, undergraduate LLB degree. ${ }^{79}$ The contents of the law degree curriculum is "lightly prescribed" by the legal professional bodies (i.e. the Law Society and the Bar Council), requiring that law graduates be educated in the "seven foundations of legal knowledge" and a range of "key skills". ${ }^{80}$ Law schools and faculties usually arrange this content in compulsory core courses comprising approximately two-thirds of the LLB degree programme - Contract Law, Criminal Law, Tort Law, Public Law, Equity and Trusts, Land Law, and European Union Law - and the remaining one-third comprising of law elective courses including Family Law,

\footnotetext{
76 lbid, 85.

77 Ibid, 87.

$78 \mathrm{lbid}, 87$

79 lbid, 80.

80 lbid, 80 .
} 
Labour Law, and Company Law. ${ }^{81}$ This is then followed by a vocational course and a requisite period of practical training under the supervision of a qualified legal practitioner. ${ }^{82}$ Differentiated vocational training programmes exist for solicitors and barristers respectively, with the former having to complete the Legal Practice Course (LPC), and the latter undertaking - since September 2020 - a Bar Course or Bar/Barrister Training Course (BTC) or Bar Practice Course (BPC). ${ }^{83}$ Curiously, these vocational courses for both aspiring solicitors and barristers involve a substantial amount of substantive knowledge compared to skills training. ${ }^{84}$ The only practical legal training prospective legal professionals therefore undergo is in the final stage of their preparation to join the legal profession, with solicitors having to complete a two-year training contract and barristers a one-year pupillage. ${ }^{85}$ If the academic, vocational, and practical stages of education and training are completed on a full-time basis, prospective candidates will qualify for admission to the profession after five continuous years of education and training. Longer, alternative routes for admission to the legal profession are also available to those who did not complete the qualifying three-year LLB degree programme. These alternative routes will not be considered here, as the focus of this article is specifically on the setting of a policy agenda for the reform of the higher education component of the conventional (undergraduate) route for admission to the legal profession in England and Wales.

In the analysis and discussion that follows, a number of recommendations will be made with regard to undergraduate legal education and training in England and Wales. These recommendations have at aim to inform and serve policy development in this regard and specifically in light of the 4IR.

\section{Recommendations For Reforming Legal Education and Training In England And Wales}

Legal professional services constitute job-tasks that cannot easily by substituted by machines, as these tasks cannot be defined in terms of codifiable rules and

\footnotetext{
$81 \mathrm{lbid}, 80$.

82 Ibid, 81.

83 Prior to these Bar Course programmes being rolled out in September 2020, aspiring barristers had to complete the Bar Professional Training Course (BPTC) and before that the Bar Vocational Course (BVC). Andrew Boon and Julian Webb, 'Legal Education and Training' supra n 75, 81.

${ }^{84}$ Andrew Boon and Julian Webb, 'Legal Education and Training' supra n 75, 81.

85 lbid, 82.
} 
algorithms. ${ }^{86}$ This is because these tasks relate, inter alia, to perception, manipulation, persuasion, negotiation, creativity, and social intelligence, are usually performed in unstructured situations, and depend on the capability of workers to orient themselves in complex situations and to react to potential failures and unstructured challenges. ${ }^{87}$ Yet, this does not mean that legal professional services are immune from any technological impact. As indicated in the introduction to this article, modern technology may fundamentally change the way in which law is practiced and clients receive their legal services. Examples abound and range "from such simple techniques as text analytics, legal research or law firm billing solutions, to more complex ones like predictive analytics and the use of blockchain." 88

In preparing prospective legal professionals for legal practice at a time when the full impact of an automated and technology-driven market is yet to be realised, higher education policy for legal education and training should ideally incorporate two focusareas: First, it should provide guidance on how the technological advances of the 4IR can be utilised for, and inform legal education and training in preparing future legal practitioners for a highly automated and technology-driven workplace. And second, it should emphasise and re-enforce those features and job-tasks associated with law and legal practice that are non-routine, and therefore not easily (or not at all) susceptible to automation. ${ }^{89}$ The latter is important, as these unique, human and cognitive capabilities, will become particularly coveted in an automated and technology-driven future.

\section{The LLB programme: Still fit for purpose?}

It is by now generally accepted that routine-based job-tasks are at a high-risk for complete automation and may result in technological unemployment. ${ }^{90}$ This has been evidenced in terms of a shifting demand from low-skill, to more skilled workers, which is generally referred to as the Skill-Biased Technological Change hypothesis

\footnotetext{
${ }^{86}$ Algorithms can be described as a "specific set of rules or directions for performing a task" or "a set of formal directions for obtaining the required solution". Tajti, 'The Impact of Technology' supra n 1, 400. Arntz et al., 'The Risk of Automation' supra n 3, 9.

87 Arntz et al., 'The Risk of Automation' supra n 3, 9.

88 Tajti, 'The Impact of Technology' supra n 1, 397. The Law Society, 'Capturing Technological Innovation in Legal Services' (2017) <https://www.lawsociety.org.uk/support-services/researchtrends/capturing-technological-innovation-report/> accessed June 2021.

${ }^{89}$ Arntz et al., 'The Risk of Automation' supra n 3, 10.

90 See, for example, Green, 'Employee Involvement' supra n 32, 36-67.
} 
(SBTC). ${ }^{91}$ More recently, job polarisation has also become prevalent across mature economies like that of the United Kingdom and Western Europe. ${ }^{92}$ Job polarisation refers to the bias of technological change to not only replace labour in routine and lowskilled tasks (routine-biased technological change (RBTC)), but also prompt the offshoring (or reshoring) of low-skill and routine tasks (itself partially influenced by technological change) to other countries and jurisdictions. ${ }^{93}$ Both SBTC and RBTC therefore decrease the demand for middling, relative to high-skilled and low-skilled occupations, and displace low-skill jobs significantly in certain countries and jurisdictions (depending on the primary drivers of the specific economy). ${ }^{94}$ While the longer term impact of an automated and technology-driven labour market remains uncertain, it is becoming clear that there will be "obvious losers from advanced technology". ${ }^{95}$ These will primarily include workers whose skills (whether low-level skills or mid-level skills) have been displaced entirely or in large part by automation, and who do not have any opportunity and/or capabilities to build on existing skills-sets and knowledge bases, or acquire a new skills-set or knowledge base in order to remain relevant and in demand for the "new" labour market. ${ }^{96}$

In the legal services sector, legal associate professionals (e.g. barrister's clerks, compliance officers, conveyancers, legal executives, and paralegals), and legal secretaries (including legal administrators, legal clerks, and secretaries in legal services), are particularly affected by SBTC and RBTC: ${ }^{97}$

\footnotetext{
91 Maarten Goos et al., 'Explaining Job Polarization: Routine-Biased Technological Change and Offshoring' (2014) 104(8) The American Economic Review, 2509. See generally Daron Acemoglu, 'Why Do New Technologies Complement Skills? Directed Technical Change and Wage Inequality' (1998) 113(4) The Quarterly Journal of Economics, 1055-1089.

${ }^{2}$ Goos et al., 'Explaining Job Polarization' supra n 91, 2509.

$93 \mathrm{lbid}$

94 Green, 'Employee Involvement' supra n 32, 36; Goos et al., 'Explaining Job Polarization' supra n 91, 2509; Autor, 'The "Task Approach" to Labour Markets' supra n 30, 185-199.

95 The Economist Intelligence Unit Ltd., The Automation Readiness Index, supra n 5, 18.

96 The Economist Intelligence Unit Ltd., The Automation Readiness Index, supra n 5, 18-19. See generally, United Kingdom Commission for Employment and Skills (UKCES), 'Working Futures 20142024' (Evidence Report 100, 2016)

<https://assets.publishing.service.gov.uk/government/uploads/system/uploads/attachment_data/file/5 13801/Working_Futures final_evidence_report.pdf> accessed June 2021.

${ }^{97}$ Matthew Williams et al., 'Research to Inform Workforce Planning and Career Development in Legal Services' (Institute for Employment Studies (IES) Report, 2018), 7 $<$ https://www.lawsociety.org.uk/support-services/research-trends/research-to-inform-workforceplanning-and-career-development-in-legal-services/> accessed June 2021. Tajti, 'The Impact of Technology' supra n 1, 416.
} 
In 1998 there were two legal professionals to one legal secretary, and the ratio was one to one when adding in other office support staff, but by 2017 the ratios had increased to five legal professionals per legal secretary, and two legal professionals for every secretary or other office support worker. In 2027, there are projected to be around twenty legal professionals per legal secretary, and five legal professionals for every secretary or other office support worker. Thus, the role of legal secretary is projected to largely vanish over the coming decade. The interviews with employers found that legal professionals were becoming increasingly self-sufficient in terms of managing their own documents and diaries, particularly new entrants to the profession, and technology solutions such as voice recognition were also reducing the need for secretarial support. Furthermore, office support roles were becoming more generalist and combining personal assistance support for fee earners with other administrative tasks. ${ }^{98}$

In contrast, the number of legal professionals (solicitors and barristers) for the period 1998 to 2016 have increased from approximately 96,000 to $161,000{ }^{99}$ But this does not necessarily mean that legal professionals are exempt from, or will remain unaffected by technological unemployment. 100 In fact, legal professionals may face an altogether different challenge in a highly automated and technology-driven labour market where an exceptionally skilled and highly qualified labour force is seemingly becoming the norm. ${ }^{101}$ For example, while the number of law students graduating with law qualifications in England and Wales has more than doubled over the last two decades - from around 15,000 in 1994 , to more than 30,000 students in $2016^{102}$ only $13 \%$ of all law graduates have over the past five years gone into legal professional positions - i.e. that of a barrister or solicitor - and only $15 \%$ went into legal associated positions in the legal and accounting sector. ${ }^{103}$ (These legal associated positions include titles such as barrister's clerks, compliance officers, conveyancers, legal executives and paralegals.) $)^{104}$ This is concerning as the current LLB degree

\footnotetext{
98 Williams et al., 'Research to Inform Workforce Planning and Career Development' supra n 97, 7-8. 99 Ibid, 26.

100 The concept "technological unemployment" was coined by David Ricardo in 1819, when he suggested that labour-saving technologies will increasingly reduce the demand for undifferentiated labour, and that this will lead to technological unemployment. David Ricardo, On The Principles of Political Economy and Taxation (John Murray 1817).

101 Andrew Boon and Julian Webb, 'Legal Education and Training' supra n 75, 110.

102 Williams et al., 'Research to Inform Workforce Planning and Career Development' supra n 97, 33.

$103 \mathrm{lbid}, 35$.

104 Ibid, 5.
} 
programme in England and Wales offers students a narrow and specialised skills-set, exclusively focussed on a foundational knowledge in law.

Moreover, only $4 \%$ of first degree law graduates went straight into legal professional jobs in the legal and accounting sector upon graduating, while $40 \%$ of law graduates also holding another professional qualification or degree went into legal professional jobs in the legal and accounting sector, and $21 \%$ of such double- or multi-qualified graduates went into legal associate professional jobs. ${ }^{105}$ In fact, it is estimated that between $20 \%$ to $30 \%$ of new solicitor admissions studied non-law subjects, ${ }^{106}$ and a 2018 report by the Institute of Employment Studies (IES) revealed that some law firms look to hire graduates from STEM backgrounds, who have both numeracy skills as well as problem-solving skills "that would be useful in a technologically-focussed environment". 107 These statistics on occupational trends in the legal professions, shows that the narrow and specialised skills-set law graduates currently acquire from their undergraduate studies, is linear and monodisciplinary, and out of touch with the new labour force which is augmented with technology and, as a consequence, enriched with interdisciplinarity.

Thus, while it will always be important for law students to acquire the foundational knowledge and skills in law, the traditional, linear, and monodisciplinary focus of the formal undergraduate law degree in England and Wales no longer suffice. Seemingly, most law graduates do not enter the law profession, and most who do, are double- or multi-qualified graduates with education and training in subject disciplines beyond that of law. An interdisciplinary and T-shaped graduate ${ }^{108}$ - i.e. a graduate with in-depth knowledge of a specific field, together with sufficient knowledge in other fields outside their own specialisation - is therefore clearly more preferred than a graduate holding only the conventional undergraduate three-year LLB degree. The possibilities this observation presents for the reform of the current LLB degree programme abound and many examples for alternatives to the current three-year undergraduate qualifying degree in law already exist (and flourish) in other jurisdictions. This includes, for

\footnotetext{
$105 \mathrm{lbid}, 35$ and 82.

106 lbid, 35.

107 lbid, 91.

108 Elaine Mak, The T-shaped Lawyer and Beyond - Rethinking Legal Professionalism and Legal Education for Contemporary Societies (Eleven International Publishing, 2017).
} 
example, the study of law at the graduate level, following the completion of a first Bachelor's degree, or the offering of more double-degree programmes allowing graduates to obtain both a law degree as well as a second degree over a longer period of study.

The dawn of the 4IR and its impact on the labour market may therefore have brought about an unanticipated, but very welcome opportunity to rethink and radically redesign the three-year LLB degree programme, a degree programme that has undergone relatively little thorough-going reform since its inception in the mid 1850s, and has always been held ransom by the out-dated view that legal higher education can only be training for legal practice. ${ }^{109}$

\section{Addressing current and projected skills gaps and skills shortages}

In an automated and technology-driven labour market, it is undoubtedly so that technical, and specifically digital and computing capabilities will become increasingly important. This is also the case for non-STEM disciplines and programmes. A 2018 report by the Institute for Employment Studies (IES) noted that technical and practical skills, including basic computer literacy and advanced or specialist IT skills, were the skills gaps ${ }^{110}$ most commonly reported by legal services employers. And in 2020, it was reported in the Oxford LawTech Survey that $90 \%$ of solicitors indicated that they would need some training concerning artificial intelligence and digital technology within the next three years, while approximately $60 \%$ of solicitors "agreed or strongly agreed that lawyers need to become familiar with multiple non-legal technical specialisms, such as data science, project management, and design thinking". ${ }^{111}$ Some of the most commonly anticipated training needs included the following: Data analytics $(71 \%)$, legal issues raised by the use of artificial intelligence and/or technology $(65 \%)$, the use and application of software packages $(61 \%)$, ethical issues raised by artificial intelligence and/or technology (48\%), digital literacy (45\%), and

\footnotetext{
${ }^{109}$ Andrew Boon and Julian Webb, 'Legal Education and Training' supra n 75, 110.

110 Skills gaps are those skills found lacking in the current workforce. Williams et al., 'Research to Inform Workforce Planning and Career Development' supra n 97.

111 Mari Sako et al., 'LawTech Adoption and Training - Findings from a Survey of Solicitors in England and Wales' (March 2020), 9 and 15

<https://www.law.ox.ac.uk/sites/files/oxlaw/oxford_lawtech_adoption_and_training_survey_report_18 march 2.pdf> accessed June 2021; Václav Janeček et al., 'Education for the Provision of Technologically Enhanced Legal Services' (2021) 40 Computer Law and Security Review, 3.
} 
innovation techniques (44\%). ${ }^{112}$ These skills are valuable for the application of various new technologies in the legal services sector, including to "automate review of legal contracts to prepare litigation cases; scan legal documentation in bulk to enhance document drafting and case citation checking; utilise natural language processing to make legal research more efficient; and use machine learning to draw research and insight from large amounts of legal data." 113

However, while surveys and reports like those mentioned above clearly highlight the need for introducing a range of technical and practical skills courses in the undergraduate LLB curriculum, "it remains unclear what particular knowledge and skills future lawyers will need in order to deploy digital technologies to theirs and their clients' advantage. It is also unclear whether these needs are part of a broader shift towards twenty-first century skills or are domain specific." 114 As already indicated, this uncertainty surrounding the possible impact and consequences of the 4IR in the legal services sector too often give way to a sense of futility that inhibits any and all (policy and strategic) action in this regard. ${ }^{115}$ This should be heeded against and the imagined future of the 4IR should rather serve as an invitation for critical reflection and innovative action. Such a pioneering outlook is seemingly already at the order of the day in larger firms and companies in the legal services industry. One of the interviewees (a legal director of a law firm) for the 2018 report by the Institute for Employment Studies (IES), explained as follows: "[W]hen recruiting, if they have to choose between two candidates with similar skills but one has coding skills, they would pick the candidate who can code as it indicates a good understanding of technology more broadly." ${ }^{116}$ A similar observation was made by Neil Lawrence, director of machine learning at Amazon: "Programming requires a way of thinking that is helpful to develop, even if you don't programme computers for a living. I used to teach programming to biologists; they learn far more than how to make a computer work."117

\footnotetext{
112 Sako et al., 'LawTech Adoption and Training' supra n 111, 9; Janeček et al., 'Education for the Provision of Technologically Enhanced Legal Services' supra n 111, 3.

113 Williams et al., 'Research to Inform Workforce Planning and Career Development' supra n 97. 114 Janeček et al., 'Education for the Provision of Technologically Enhanced Legal Services' supra n $111,2$.

115 The Economist Intelligence Unit Ltd., The Automation Readiness Index, supra n 5, 21.

116 Williams et al., 'Research to Inform Workforce Planning and Career Development' supra n 97, 94.

117 Incidentally, the application of artificial intelligence techniques in the learning process has also been said to be beneficial to (legal) educators, who, through studying and experimenting with $\mathrm{Al}$
} 
Thus, in line with the recommendation above for a multi-disciplinary or T-shaped law graduate, undergraduate law students should also acquire "a broad foundation of knowledge and awareness of technology and its potential applications, and a set of soft skills that facilitate the introduction and usage of new technologies within different workplaces and teams." 118 Such additional layers of knowledge and skill will foster a mindset of understanding across disciplinary boundaries, promote data-oriented thinking and commercial awareness, and encourage an innovate but ethical, and a systems-oriented approach with regard to law and legal practice. ${ }^{119}$

But technological, and specifically digital and computing capabilities, are not the only skills that will be highly sought-after in future. A high premium will in future also be placed on those qualities and skills that cannot be mimicked by machines or displaced by automated processes. So-called twenty-first century skills that are less likely (or more difficult) to be substituted by machines and computers, include human interactive and cognitive capabilities including critical thinking, empathetic communication and caring, collaboration, creativity, and problem-solving skills. ${ }^{120}$ These skills are at present already found lacking or insufficient amongst the existing workforce of the legal services sector. For example, in the 2018 report by the Institute for Employment Studies (IES) it was noted that the present skills shortages ${ }^{121}$ reported by employers in the legal services sector include problem-solving skills, client handling skills, teamwork skills and general literacy (i.e. the writing, reading and understanding of instructions, guidelines, manuals or reports). ${ }^{122}$ In addition, consistent increases were also noted in the proportion of employers citing the following skills shortages: Planning and organisation skills (up from $28 \%$ in 2011 to $47 \%$ in 2017), team working skills

applications in their pedagogy, ultimately "gain a much deeper understanding of how their students actually learn". The Economist Intelligence Unit Ltd., The Automation Readiness Index, supra n 5, 16 118 Janeček et al., 'Education for the Provision of Technologically Enhanced Legal Services' supra $\mathrm{n}$ $111,2$.

119 lbid, 5-6.

120 Autor et al., 'The Skill Content' supra n 4, 1284; Arntz et al., 'The Risk of Automation' supra n 3 , 14.

${ }^{121}$ Skills shortages refer to those skills employers have difficulty in finding amongst job applications. Williams et al., 'Research to Inform Workforce Planning and Career Development' supra n 97, 26 and 40.

122 Williams et al., 'Research to Inform Workforce Planning and Career Development' supra n 97, 3, 67, 45 and 48-49. 
(from 16\% in 2011 to $30 \%$ in 2017), and basic computer literacy/lT skills (up from 6\% in 2011 to $16 \%$ in 2017$).{ }^{123}$

The 2018 report further revealed that law firms "were paying more attention to softer people skills, such as communication and team working, when recruiting legal professionals, whereas in the past they had only looked at the technical legal skills."124 Law firms were apparently of the view that technical skills could be learnt on the job, while soft skills like those already mentioned, in conjunction with commercial awareness, good client and colleague relations and the business environments in which they operate, were seen as equally important to academic achievement at the recruitment stage. ${ }^{125}$ These interactive and cognitive capabilities, together with valuable character and personality traits (including emotional maturity), will become even more highly desired in an automated and technology-driven labour market. ${ }^{126}$ Green explained as follows:

One common organisational change [from technological advancement] is the increase in employee involvement in companies - meaning workers are becoming better informed about their employer, participating in discussions about immediate production issues or wider organisational matters, working as members of teams, participating in profit-sharing reward schemes or similar performance-based incentives, being trained to perform jobs designed for greater autonomy, and being a part of other associated delayering of management functions. [...] These practices have implications for skills utilisation that run parallel with the demands of computer technologies. [...] There is thus more need for workers to think proactively and more scope for problem-solving. Second, there is likely to be an increased need for interaction skills in order to function well in high-involvement corporate environments. In situations that require employees to work together more often and cooperate with colleagues, to exchange information and express opinions, and to learn and adopt at least some of the organisation's common values and attitudes, communication activities acquire a greater range and importance in their jobs. Since a good deal of communication also occurs through the medium of the written word (on paper or on

\footnotetext{
123 Williams et al., 'Research to Inform Workforce Planning and Career Development' supra n 97, 3, 15-16, and 53 .

124 Ibid, 7.

125 Ibid, 11 and 90.

126 Autor et al., 'The Skill Content' supra n 4, 1285; See, for example, 'Department for Education (UK), Policy Paper National Retraining Scheme' supra n 67.
} 
screen), employee involvement also increases the importance of literacy. In an environment of relatively increased participation, there is also more call for the higher forms of communication that are entailed in facilitating learning and inducing others to follow desired courses of action. ${ }^{127}$

To this can be added the increased importance of creativity and critical thinking for an automated and technology-driven labour market. Creativity refers to the "ability to develop new and meaningful ideas or artefacts such as new concepts, theories, literature, or musical compositions". ${ }^{128}$ In law and legal practice, problem solving which is at the heart of lawyering - is dependent on creativity:

The creative legal problem solver [...] must learn to navigate within the seas of optimistic creativity, the swells of dynamic interaction with others (client and other counsel and parties) and the oceans of realistic legal possibility. ${ }^{129}$

Such creative problem solving also requires critical thinking to find solutions to thorny and weighty legal problems. Creativity and critical thinking are therefore important for new and novel solutions, legal concepts, and applications for our current and every changing contexts. ${ }^{130}$

It is submitted that "soft" human-centred skills are not only less likely (or more difficult) to be substituted by machines and computers, but are also more likely to hold a special value in the automated workplace. ${ }^{131}$ This is because there are generally also "a strong societal preference for the provision of certain tasks and services by humans as opposed to machines." 132 Legal professionals should therefore build on this "societal value attached to humans performing certain tasks" in securing their position in an automated and technology-driven labour market. ${ }^{133}$

\footnotetext{
127 Green, 'Employee Involvement' supra n 32, 39.

128 Arntz et al., 'The Risk of Automation' supra n 3, 9.

129 Carrie Menkel-Meadow, 'Aha? Is Creativity Possible in Legal Problem Solving and Teachable in Legal Education?' (2001) 6 Harvard Negotiation Law Review, 102-103.

130 Arntz et al., 'The Risk of Automation' supra n 3, 9.

131 The Economist Intelligence Unit Ltd., The Automation Readiness Index, supra n 5, 16.

${ }^{132}$ Arntz et al., 'The Risk of Automation' supra n 3, 22.

133 Ibid, 22.
} 
Robots cannot tell stories. As we move into a world where more and more services are being provided in commoditised, automated ways, lawyers can craft personalised stories: stories that evoke images to make clients more sympathetic, that sway juries and judges, and that communicate in the world of public opinion. Situations in which the lawyer as storyteller is a powerful force will remain as those in which traditional lawyering will have a considerable strategic advantage over new entrants into the legal services market. ${ }^{134}$

\section{Global mindedness and mobility}

Policies aimed at ensuring, or at least enabling greater mobility of law graduates between different legal jurisdictions and even within one jurisdiction but amongst different roles - e.g. barrister, solicitor, paralegal, prosecutor etc. - will be valuable in offsetting work displacement resulting from the 4IR. This will become increasingly important as traditional work structures and job-tasks come under pressure due to automation, whilst new job opportunities arising will inevitably be embedded in global industries demanding of more than just localised skills and knowledge.

An obvious starting point to promote global mindedness in the LLB curriculum, is by way of comprehensive internationalisation which goes beyond the mere offering of exchange or other study abroad programmes. ${ }^{135}$ Such comprehensive internationalisation would include, for example, the option for students to enrol in a second or third language as part of their degree offering, infusing existing core and elective law modules with international, transnational and comparative perspectives, promoting internships and work placements abroad, and ensuring that students have the opportunity to attend presentations or be taught by international faculty. The global competence so acquired, will assist law graduates to work across jurisdictions; a valuable and imperative capability as global connectivity continues to grow, and the world continues to shrink. Yet, this is seemingly no longer enough as legal practitioners who are exclusively educated and trained in the local (national) laws and legal practices will find it increasingly difficult to participate and be competitive in the

${ }^{134}$ Raymond Brescia, 'Law and Social Innovation: Lawyering in the Conceptual Age' (2016/17) 80 Albany Law Review, 166.

135 Jos Beelen and Elspeth Jones, 'Redefining Internationalisation at Home' in Adrian Curaj et al. (eds.) The European Higher Education Area: Between Critical Reflections and Future Policies (Springer, 2015), 60. 
globalised legal services market. ${ }^{136}$ This is not only because of the global connectedness and increasing transnational nature of law and legal practice, but also because of the influence and cross-fertilisation of the laws and legal practices of different countries and jurisdictions on one another.

One reason for the increasing influence of foreign laws and practices on the domestic front, is the accessibility of authoritative law sources either on the internet or through comprehensive comparative law databases. This "radically advanced access not only to international and foreign laws but also to domestic laws", 137 can be ascribed to advanced digitalisation technology, the Internet of Things, and the more recent intensified application of algorithms in the realms of law. Particularly important for the discussion here, is that the aggregate effect of these technological advances are fundamentally changing legal practice as well as law reform. Legal practice and law reform are no longer just inward looking but are increasingly engaged, in a multitude of ways and to various ends, with the laws and legal practices of other jurisdictions. ${ }^{138}$ Thus, while law has emerged from the nation state as "a national product where local interests, perceptions, and idiosyncrasies, rather than communalities with other systems prevail," 139 and while the primary focus of higher education policy for legal education and training will for this reason always be on the science of law in a particular country or jurisdiction, the increasing influence and potential of foreign law and legal practices in the local or national domain necessitate some awareness and competence in the laws and legal practices of other jurisdictions. Globally competent legal practitioners today, must therefore be able to

...investigate the world beyond their immediate environment by examining issues of local, global and cultural significance. [...] recognise, understand and appreciate the perspectives of others. [...] communicate ideas effectively with diverse audiences by engaging in open, appropriate and effective interactions across cultures [...] [and]

\footnotetext{
136 Tajti, 'The Impact of Technology' supra n 1, 402.

$137 \mathrm{Ibid}, 398$.

138 Ibid, 417.

139 lbid, 416.
} 
take action for collective well-being and sustainable development both locally and globally. ${ }^{140}$

Greater mobility of law graduates within one jurisdiction, in turn, can be achieved by deregulating the legal profession, specifically by relaxing licencing requirements for entry into the various branches of the legal profession or legal practice more generally. ${ }^{141}$ It is evident that the Law Society of England and Wales and its regulatory body, the Solicitors Regulation Authority (SRA), have already made great strides in this regard. From 2021 onwards, prospective solicitors will gain admission to the profession by way of a new Solicitors Qualifying Examination (SQE). ${ }^{142}$ The existing framework for the education, practical training and qualifying requirements for admission to the legal profession was set out earlier in this article. The new Solicitors Qualifying Examination (SQE) aims to simplify this process by offering one final, common entrance examination instead of the Legal Practice Course (LPC) currently being offered by a number of different service providers, each with their own assessment requirements and standards. ${ }^{143}$

In addition to providing a one-stop common qualifying examination, the new Solicitors Qualifying Examination (SQE) will also allow for multiple pathways to this final, common entrance examination, thereby addressing the various obstacles law graduates currently face on the road to gaining admission to the profession. ${ }^{144}$ These obstacles include the cost of the LPC programme and securing a training contract in order to comply with the requisite two-year practical legal training component of the admission process. The cost of the requisite LPC programme at present, is estimated at $£ 15,000$, and even upon completion of this vocational course prospective legal practitioners find it difficult to secure a training contract. ${ }^{145}$ The new Solicitors

140 Organisation for Economic Cooperation and Development (OECD), 'PISA 2018 Global Competence' (2018) <http://www.oecd.org/pisa/pisa-2018-global-competence.htm> accessed June 2021.

141 The Economist Intelligence Unit Ltd., The Automation Readiness Index, supra n 5, 19.

142 Williams et al., 'Research to Inform Workforce Planning and Career Development' supra n 97, 97.

143 Around 110 UK universities assess students on the Qualifying Law Degree (i.e. the LLB degree programme), the Common Professional Examination (CPE), and the Legal Practice Course (LPC). Solicitors Regulation Authority (SRA), 'A New Route to Qualification: The Solicitors Qualifying Examination' (October 2016), 5 <https://www.sra.org.uk/globalassets/documents/sra/consultations/sqe-summarydocument.pdf?version=4a1ad1 $>$ accessed June 2021.

${ }^{144}$ Solicitors Regulation Authority (SRA), 'A New Route to Qualification; supra n 143, 5. 145 lbid, 5. 
Qualifying Examination (SQE) addresses both these barriers, as its roll-out will make the LPC completely obsolete as a requirement for gaining admission to practice law as a solicitor, and it will also recognise various forms and periods of supervised legal work experience towards the practical legal training component required for admission to the profession. To date, prospective solicitors must complete a two-year training contract subsequent the completion of the LPC. Under the SQE, however, periods of experience acquired in a variety of ways can now contribute to the requisite practical legal training, including work experience under a formal training contract, work at a student law clinic, work as an apprentice or a paralegal, and work experience gained through placement as part of a sandwich degree. ${ }^{146}$

This new, simplified route for admission to the legal profession will serve as another impetus for law schools and faculties to invest in thorough-going reform of their current LLB curriculum, by incorporating, for example, some (or all) of the substantive legal courses previously offered under the LPC, as part of the LLB degree programme. Under the current legal education and training framework, the LPC has always inhibited the undertaking of radical curriculum reform as there is, at present, little or no market advantage for LLB providers to go beyond the "seven foundations of legal knowledge" and a range of "key skills" as exemplified in the LLB compulsory core courses and law electives. ${ }^{147}$ Indeed, in "the world of the enterprise university, where the employability agenda is writ increasingly large," law schools and faculties will arguably for the first time in England and Wales - have both the opportunity, as well as the will to radically rethink their undergraduate (and graduate) degree offering. ${ }^{148}$ There is also no doubt that the opportunity the SQE provides to measure and compare the performance of law graduates at a national level, will be a critical factor for law schools and faculties in safeguarding their reputations, and positioning themselves in the higher education market.

The new Solicitors Qualifying Examination (SQE) was met with harsh criticism. Interviews conducted by the Institute for Employment Studies (IES) for its 2018 report, indicated that there were concern amongst legal professionals as to how the new

\footnotetext{
146 Ibid, 7.

147 Andrew Boon and Julian Webb, 'Legal Education and Training' supra n 75, 104.

148 Ibid, 112.
} 
Solicitors Qualifying Examination (SQE) will impact on the academic standard of candidates and their level of technical legal skills and vocational knowledge. ${ }^{149}$ Most criticism, however, clearly reflected that the primary concern was actually with the gatekeeping role the legal profession has always enjoyed:

[B]roadening access to becoming a qualified solicitor could potentially flood the market with applicants. [...] there would be a rush among their [the law firms'] nonqualified fee earners to become qualified solicitors once the SQE is introduced, which would not necessarily match their current business need in terms of staff profiles/roles. ${ }^{150}$

Some law firms did, however, recognise the important role the Solicitors Qualifying Examination (SQE) can play in making it possible for individuals from "non-traditional routes" to gain admission to the legal profession. These law firms were positive "about establishing multiple routes to qualification and the diversity of talent this will bring. [...] and were in favour of opening up the profession to individuals from a broader range of backgrounds." 151 Indeed, the possibilities the SQE offers with regard to the increased mobility of legal professionals and access to the legal profession, together with the opportunity it creates for the radical reform of the LLB curriculum, has not yet fully been realised. ${ }^{152}$

While the new Solicitors Qualifying Examination (SQE) was met with harsh criticism, further proposals by the Solicitors Regulation Authority (SRA) to relax the regulation of solicitors, were seemingly more acceptable to the legal profession. The Solicitors Regulation Authority (SRA) ${ }^{153}$ is currently proposing a series of reforms which will allow, inter alia, for solicitors to provide legal services on a freelance basis, or to carry out "non-reserved" legal work within a business not regulated by a legal services regulator like the SRA or others. ${ }^{154}$ Such allowances will be subject to certain

\footnotetext{
149 Williams et al., 'Research to Inform Workforce Planning and Career Development' supra n 97, 97.

$150 \mathrm{lbid}, 97-98$.

151 lbid, 98.

152 Andrew Boon and Julian Webb, 'Legal Education and Training' supra n 75, 109.

153 The Solicitors Regulation Authority (SRA) regulates solicitors and law firms of England and Wales, as well as non-lawyers of law firms regulated by the SRA, and other types of legal professionals such as registered foreign lawyers (RFLs) and registered European lawyers (RELs).

154 The legal services sector of England and Wales is governed and regulated by a number of bodies, like the Solicitors Regulation Authority (SRA), the Bar Standards Board (for barristers), and the Intellectual Property Regulation Board (IPReg) for patent and trade mark attorneys, to name just a
} 
limitations including that the solicitors and/or the businesses for which they work would not be able to hold client money and would not be required to have indemnity insurance. ${ }^{155}$ While this effort at relaxing the otherwise strict regulation of the solicitors' profession has received a mixed response, with some even warning that it may lower standards across the profession despite lawyers in unregulated entities still having to adhere by the SRA Code of Conduct under these proposed changes, ${ }^{156}$ the work of the Law Society and the Solicitors Regulation Authority (SRA), nevertheless show an awareness that "one size, increasingly, doesn't fit either all students or all employers". 157 And in an automated and technology-driven labour market, the strategies of the Law Society and the Solicitors Regulation Authority (SRA) are bound to pay off.

\section{Lifelong learning and work-placed learning}

Lifelong learning has become an area of rich experimentation in the wake of the 4IR. This is primarily because job tasks will continuously be redefined as technology continue to develop and permeate the labour market, "requiring the constant updating of skills." 158 Singapore, for example, "is experimenting with funding 'individual learning accounts' which adults use to support training courses throughout their lives. [While] Germany's Federal Ministry of Labour and Social Affairs is examining a similar scheme, as well as a modified form of 'employment insurance' to fund skills upgrading throughout people's lives." 159

In the legal services sector in England and Wales, programmes for staff training and development vary. Medium to large-sized firms are generally able to offer formal inhouse programmes to meet the ongoing training and development needs of their current employees. ${ }^{160}$ Such training include general induction programmes to new employees or to existing employees on new systems, procedures, or technology, training around compliance issues like money laundering, cyber-crime and data

few. Williams et al., 'Research to Inform Workforce Planning and Career Development' supra n 97, 96.

155 Williams et al., 'Research to Inform Workforce Planning and Career Development' supra n 97, 96-

97.

156 lbid, 96-97.

157 Andrew Boon and Julian Webb, 'Legal Education and Training' supra n 75, 109.

158 The Economist Intelligence Unit Ltd., The Automation Readiness Index, supra n 5, 7.

$159 \mathrm{lbid}, 6$.

160 Williams et al., 'Research to Inform Workforce Planning and Career Development' supra n 97, 92. 
protection regulations, as well as training on business behavioural skills and commercial awareness such as customer care, management skills, and marketing. ${ }^{161}$ For smaller firms such training is not available at all, or is outsourced to external service providers at considerable cost. ${ }^{162}$

It is submitted that law schools and faculties can play an important role in meeting the ongoing training and development needs of service providers in the legal sector, also in addressing current and projected skills gaps and shortages, and providing opportunities for specialisation. In its 2019 report the Law Society of England and Wales noted that "it is likely that new and existing staff will require training to facilitate tech adoption, to maximise any efficiencies and cost savings that tech might generate." ${ }^{163}$ Lifelong learning and other vocational programmes may also be valuable to legal secretaries and legal associate professionals who, as indicated earlier, are expected to experience some technological unemployment as a result of automation and work displacement. For these workers, retraining and/or further education or vocational training will be critical in ensuring their continued employability in the legal services sector.

In addition to the importance of lifelong learning, the multiple pathways established under the SQE for compliance with the requisite period of practical legal training for admission to the legal profession will also place a renewed focus on work-based learning and the role law schools and faculties can play in securing work-based learning opportunities such as internships for their students, or having an active and effective law clinic or similar programme where students can acquire valuable skills. ${ }^{164}$ Fostering closer ties, and collaborating with the legal services sector will for this reason become even more important than it already is.

\section{Conclusion}

Whether the Fourth Industrial Revolution will result in widespread technological unemployment, or is merely another wave of technological innovation and

\footnotetext{
161 lbid, 92.

162 Ibid, 4 and 92.

163 Ibid, 20.

164 Andrew Boon and Julian Webb, 'Legal Education and Training' supra n 75, 105.
} 
development, a robust policy response informed by multi-stakeholder engagement is imperative to ensure a long-term strategy for education and training in an automated economy. ${ }^{165}$ To date, the policy (re)action is seemingly slow, and even more so in the context of higher education beyond the STEM disciplines.

While legal professional services are, by their very nature, not at a high risk for complete or substantial automation, ${ }^{166}$ the impact of the Fourth Industrial Revolution on law and legal practice will ultimately depend on whether and how the legal profession adapts and adjusts to the new challenges it poses, opportunities it presents, and the demands it may generate. The focus of this article was specifically on higher education policy in the wake of the Fourth Industrial Revolution, and more specifically had at aim to set an agenda for legal higher education policy in England and Wales. It was shown in this article that an overt concern with the STEM disciplines, or technological unemployment, or the challenges advanced technologies may bring for the labour market, need not be the only focus of higher education policy and reform. The potential opportunities the Fourth Industrial Revolution may bring, must also be seized. It was evident in the context of law and legal practice that the Fourth Industrial Revolution may very well serve as a catalyst for unanticipated change in how legal education and training in England and Wales have been conceived up to now; possibly providing an opportunity for a complete overhaul of an old sacred cow. ${ }^{167}$

While the legal services sector of England and Wales is seemingly ready to embrace both the challenges as well as the opportunities the Fourth Industrial Revolution may bring, the action on the policy front, as well as at law schools and faculties, remain wanting. The goal of this article was to address this lacuna by setting a policy agenda that can inform the radical reform or rethinking of undergraduate legal higher education and training in England and Wales, and to ultimately ensure that law graduates are better equipped for the automated and technology-driven labour market of the future. To this end, a number of concrete recommendations were made which fundamentally challenged the tenets upon which undergraduate legal education and training in

\footnotetext{
165 The Economist Intelligence Unit Ltd., The Automation Readiness Index, supra n 5, 5 and 7; Mokyr et al., 'The History of Technology' supra n 2, 35.

${ }^{166}$ Arntz et al., 'The Risk of Automation' supra n 3, 14.

167 Tajti, 'The Impact of Technology' supra n 1, 423.
} 
England and Wales are currently based. This, it was argued, is necessary as the present linear and monodisciplinary nature of undergraduate legal education and training in England and Wales, does not only leave law graduates ill-equipped for the future labour market, but also misses the central importance and value of tasks that legal professionals uniquely supply. ${ }^{168}$

168 David Autor, 'Why are there still so many jobs? The History and Future of Workplace Automation and Anxiety' (MIT IDE Research Brief, 2016), 2. 